\title{
HAEMATOLOGICAL STUDY OF FRUIT BAT, Cynopterus Tithaecheilus
}

\author{
Anisa Rahma ${ }^{\text {a) }}$, Desrayni Hanadhita ${ }^{\text {b) }}$, Andhika Yudha P. ${ }^{\text {c) }}$, Danang D. Cahyadi \\ ${ }^{\text {d) }}$, Supratikno ${ }^{\text {e) }}$, Hera Maheshwari ${ }^{\text {f) }}$, Aryani Sismin Satyaningtijas ${ }^{\text {g) }}$, Srihadi \\ Agungpriyono $^{\text {h)* }}$
}

Department of Anatomy Physiology and Pharmacology, Faculty of Veterinary Medicine, Bogor Agricultural University (IPB), Bogor 16680, Indonesia

\author{
a) rahmaanisa31@gmail.com \\ b) desraynihanadhita@gmail.com \\ c) andhikayudhaprawira60@gmail.com \\ d) danang.dwicahyadi@gmail.com \\ e) supra_koko@yahoo.com \\ f) hera_maheshwari@yahoo.com \\ g) niekesis@yahoo.co.id \\ h) Corresponding author: ysrihadi@ipb.ac.id
}

\begin{abstract}
Haematological profile is important to determine the physiological condition of an individual, and morphology of red blood cells can also be helpful in making a diagnosis of a disease. The size of red blood cells affects the ability of red blood cells to carry oxygen. In some clinical events shape and size of red blood cells will be changed. Bats are the only mammals that have the ability to fly. The ability of bats to fly would require bats to be able to bind more oxygen, therefor bat should have enough of energy while flying. The present study was conducted on 12 Cynopterus tithaecheilus ( 7 males and 5 females) to study about haematological profile. Blood samples were taken using tuberculin needle and analyzed by hematology analyzer for hematological value. Size of red blood cells was taken using bloods smear and analyzed by imageJ software. Cynopterus tithaecheilus show the higher number of red blood cells, but the size were smaller compared to the other mammals which has same body size. Mean while the concentration of hemoglobin and hematocrit were higher. The present result suggested that these haematological values might provide a greater transport oxygen capacity in the Cynopterus tithaecheilus.
\end{abstract}

Keywords: bat, Cynopterus tithaecheilus, hematological of bat, size of red blood cell 


\section{INTRODUCTION}

Bats are the second largest diversity in the class of mammals after rodentia (Nurfitrianto et al. 2013). Bats are the only mammal that have wings and the ability to fly. Bat as a flying mammal do not have air sacs like birds, therefore bats must fulfil the energy requirement through an adaptation of the cardiovascular system. The ability of bats to fly is demanding larger heart size than the other mammals (Canals et al. 2005).

The cardiovascular system consists of heart, blood vessels, and blood. Blood is one of the most important substance in the living organisms. Haematological profile is important to determine the physiological condition of every individual. Blood profiles in the normal range represent normal physiological condition which is different among specieses (Shawaludin et al. 2013). Blood cell are composed of erythrocytes, leukocytes, and platelets. Erythrocytes use to carry oxygen and nutrients throughout the body. Leukocytes is the body's defense system, while platelets are blood clotting factor.

The ability of erythrocytes to carry oxygen is affected by its size (Harthman and Lessler 1963). Nowaczewski and Kontecka (2012) states that the size of erythrocytes is different for each species and gender. Shape and size of the erythrocytes may change in some clinical event. Morphology of individual erythrocytes can also be helpful in making a diagnosis of a disease (Warni 2009). The incidence on certain internal membrane cytoskeleton can change the origin shape of the membrane of erythrocytes (Richards et al. 2000). This study was conducted to observe the erythrocytes characteristics in Cynopterus tithaecheilus

\section{MATERIALS AND METHODS}

This study was conducted using 12 Cynopterus tithaecheilus (5 females and 7 males) which were captured in Garut, Indonesia. Cynopterus tithaecheilus which had been captured were taken to the laboratory of Anatomy, Department of Anatomy Physiology and Pharmacology, Faculty of Veterinary Medicine IPB, and then anaesthetized using $10 \mathrm{mg} / \mathrm{kg}$ ketamine and $2 \mathrm{mg} / \mathrm{kg}$ xylazine (Sohayati et al., 2008). Blood sample was collected from the heart as much as $0.3 \mathrm{ml}$ using tuberculin needle and stored in $0.5 \mathrm{ml}$ EDTA botlle. Blood was analyzed using haematology analyzer to determine the value of erythrocytes (RBC), haemoglobin, and haematocrit, mean corpuscular volume (MCV), mean corpuscular haemoglobin $(\mathrm{MCH})$ and mean corpuscular haemoglobin concentration (MCHC). Blood smear preparation was done to analyze the morphology of erythrocytes to obtain total area of erythrocytes using Image $\mathbf{J}$ as shown below.



FIGURE 1 Eryrocytes was analyze use Image J 


\section{RESULT}

The present result on value of $\mathrm{RBC}$, haemoglobin, and haematocrit, $\mathrm{MCV}, \mathrm{MCH}$, MCHC and size of erythrocyte are summarized in table.Table 1 showed the comparison haematology profile between male Cynopterus tithaecheilus with the other mammals and Table 2 showed the haematology profile between female Cynopterus tithaecheilus with other mammals.

Table 1 Comparative Haematology profile of male fruit bat (Cynopterus tithaecheilus) with other mammals

\begin{tabular}{|c|c|c|c|}
\hline \multirow[t]{3}{*}{ Parameter } & \multicolumn{3}{|c|}{ Species } \\
\hline & C. tithaecheilus & Mice & Rat \\
\hline & & Wolford et al. 1986 & Wolford et al. 1986 \\
\hline $\operatorname{RBC}\left(10^{6} / \mu\right)$ & $11.23 \pm 0.870$ & $9.11 \pm 0.697$ & $7.82 \pm 0.831$ \\
\hline$H b(g / d L)$ & $15.36 \pm 1.168$ & $15.4 \pm 1.05$ & $14.7 \pm 1.22$ \\
\hline Het $(\%)$ & $45.57 \pm 2.609$ & $42.6 \pm 3.22$ & $39.9 \pm 3.49$ \\
\hline MCV (fL) & $40.57 \pm 1.988$ & $46.8 \pm 1.82$ & $51.3 \pm 3.00$ \\
\hline MCH (Pg) & $13.67 \pm 0.797$ & $17.0 \pm 0.79$ & $19.0 \pm 1.09$ \\
\hline MCHC (g/dL) & $33.63 \pm 0.749$ & $36.3 \pm 1.26$ & $37.0 \pm 0.95$ \\
\hline Area $\left(\mu m^{2}\right)$ & $31.24 \pm 5.560$ & - & - \\
\hline
\end{tabular}

Table 2 Comparative Haematology profile of female fruit bat (Cynopterus tithaecheilus) with other mammals

\begin{tabular}{cccc}
\hline Parameter & \multicolumn{3}{c}{ Spesies } \\
& C. tithaecheilus & $\begin{array}{c}\text { Mice } \\
\text { Wolford } \text { et al. } 1986\end{array}$ & $\begin{array}{c}\text { Rat } \\
\text { Wolford } \text { et al. } 1986\end{array}$ \\
\hline RBC $(\mathbf{1 0} / \boldsymbol{\mu})$ & $11.04 \pm 0.831$ & $8.74 \pm 0.689$ & $7.27 \pm 0.513$ \\
Hb $(\mathbf{g} / \mathbf{d L})$ & $15.08 \pm 1.136$ & $15.0 \pm 0.90$ & $14.3 \pm 0.83$ \\
Hct $\mathbf{( \% )}$ & $44.89 \pm 3.201$ & $41.0 \pm 3.23$ & $38.1 \pm 2.43$ \\
MCV $(\mathbf{f L})$ & $41.00 \pm 3.391$ & $46.9 \pm 1.86$ & $52.6 \pm 2.27$ \\
MCH (Pg) & $13.64 \pm 0.909$ & $17.3 \pm 0.90$ & $19.8 \pm 0.94$ \\
MCHC $(\mathbf{g} / \mathbf{d L})$ & $33.56 \pm 0.983$ & $36.7 \pm 1.59$ & $37.6 \pm 1.00$ \\
Area $\left(\boldsymbol{\mu \mathbf { m } ^ { 2 }}\right)$ & $33.56 \pm 5.302$ & - & - \\
\hline
\end{tabular}

Based on the Table1 and Table 2 showed the Cynopterus tithaecheilus have the larger value of erythrocytes, haemoglobin, and haematocrits than other mammals. Erythrocytes value of male Cynopterus tithaecheilus was (11.23 \pm 0.870$) 10^{6} / \mu$, its number was higher than mice and rat that has an erythrocytes value was $(9.11 \pm 0.697) 10^{6} / \mu$ and $(7.82 \pm 0.831) 10^{6} / \mu$ (Wolford et al. 1986). Haemoglobin of male Cynopterus tithaecheilus was not different

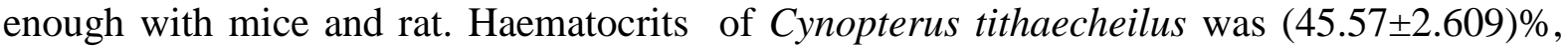
that number is higher than a mice was $(42.6 \pm 3.22) \%$ and rat was $(39.9 \pm 3.49) \%$ (Wolford et al. 1986). Female Cynopterus tithaecheilus also has a higher value of erythrocyte, haemoglobin and haematocrit than mice and rat which erythrocyte value was $(11.04 \pm 0.831)$ $10 \%$, haemoglobin was $(15.08 \pm 1.136) \mathrm{g} / \mathrm{dL}$ and haematocrits $(44.89 \pm 3.201) \%$. 
Based on the Table1 and Table2 also show the Cynopterus tithaecheilus have MCV, $\mathrm{MCH}$, and MCHC smaller than the other mammals. Male Cynopterus tithaecheilus MVC was (40.57 \pm 1.988$) \mathrm{fL}, \mathrm{MCH}$ was $(13.67 \pm 0.797) \mathrm{Pg}$, and $\mathrm{MCHC}$ was $(33.63 \pm 0.749) \mathrm{g} / \mathrm{dL}$. Female Cynopterus tithaecheilus MCV was $(41.00 \pm 3.391) \mathrm{fL}, \mathrm{MCH}$ was $(13.64 \pm 0.909) \mathrm{Pg}$ and MCHC was $(33.56 \pm 0.983) \mathrm{g} / \mathrm{dL}$. The present result showed that erythrocytes size for male Cynopterus tithaecheilus was $(31.24 \pm 5.560) \mu \mathrm{m}^{2}$ and female was $(33.56 \pm 5.302) \mu \mathrm{m}^{2}$.

\section{DISCUSSION}

Haematology is important to determine the health status, includes information about the nutritional status and stress conditions (McMichaael et al. 2015; Hossain et al. 2013), which is needed to determine conservation status and populations management (Hall et al. 2014). Bats are known to have higher haematocrit and haemoglobin levels than other mammals with the same size (Maina 2000). Haematological data will be very helpful for defense system, to state physiological conditions of the bat.

Blood carry oxygen and others substances that are needed by living organisms to survive (Shawaludin et al. 2013). Haemoglobin levels will be positively correlated with the number and size of erythrocytes in physiologic state. The higher levels of haemoglobin, the more oxygen can be bound. This present study showed no significant differences of haematological value in both male and female of Cynopterus tithaecheilus. Cynopterus tithaecheilus has a higher erythrocytes count and haemoglobin value than other mammals with the same body size therefore they may able to carry more oxygen. This characteristics might support the ability to fly which require a high energy.

Female Cynopterus tithaecheilus erythrocytes count was lower than male Cynopterus tithaecheilus but female erythrocytes size was larger $\pm 2 \mu \mathrm{m}^{2}$ than male. Erythrocytes of Cynopterus tithaecheilus were smaller than mice and rats. Even though bats has small size of erythrocytes but its size still can carry amount of oxygen which needed to fly. The ability to bring a huge of oxygen will be very useful for the bat to meet its energy needs, especially when flying. The value of MCV and $\mathrm{MCH}$ were small, but we suggested small value of MCV and MCH may be followed by rapid haematopoiesis process that Cynopterus tithaecheilus reach a higher number of erythrocyte.

\section{CONCLUSION}

Erythrocyte Cynopterus tithaecheilus size are smaller than erythrocyte of other mammals. The small size of erythrocyteis followed by higher of erythrocyte count and higher haemoglobin level, that Cynopterus tithaecheilus can fullfil the energy to fly.

3. FA Harthman \& MA Lessler, in Erythrocyte Measurements in Fishes, Amphibia and Reptiles. (Department of Physiology, Ohio State University Inc., Columbus), 1963 
4. MB Hossain et al., Jurnal Veteriner Medicine, 11(1), 75-79, 2013

5. JN Maina, Jurnal of Experimental Biology, 203, 3045-3064, 2000

6. L McMichael et al., Jurnal Plos One, 10 ,1-13, 2015

7. S Nowaczewski \& H Kontecka, Animal Science Paper and Report, 30,181-190, 2012

8. H Nurfitrianto et al., Jurnal Lentera Bio, (2)2,143-148, 2013

9. WD Ratnasooriya et al., Journal of Science, 2, 27-40, 2005

10. RS Richards et al., Journal of Chronic Fatigue Syndrome, 6, 23-35, 2000

11. A Shawaludin et al, Jurnal Ilmiah Peternakan, 1, 1001-1013, 2013

12. AR Sohayati et al., Journal of Zoo and Wildlife Medicine, 39 (4), 674-676, 2008

13. E Warni, Jurnal Ilmiah Elektrikal Enjiniring, 7, 1-9, 2009

14. ST Wolford et al., Jurnal of Toxicology and Enviromental Health, 18(2), 161-188, 2009 